\title{
IP-10 Decreases TNF- $\alpha$ Induced MUC5AC Expression in Human Airway Epithelial Cells: a Possible Relation with Little Sputum Production in Idiopathic Pulmonary Fibrosis
}

Division of Pulmonology, Department of Internal Medicine, College of Medicine, The Catholic University of Korea, Seoul, Korea

Seung Joon Kim, M.D., Chun Mi Kang, Moon Bin You, M.D., Hyung Kyu Yoon, M.D., Young Kyoon Kim, M.D., Kwan Hyoung Kim, M.D., Hwa Sik Moon, M.D., Sung Hak Park, M.D., Jeong Sup Song, M.D.

\section{IP-10에 의한 기도상피세포에서의 TNF- $\alpha$ 유도 MUC5AC발현 억제: 특발성폐섬유증 환자의 적은 객담과의 연관성}

김승준, 강춘미, 유문빈, 윤형규, 김영균, 김관형, 문화식, 박성학, 송정섭

가톨릭대학교 의과대학 내과학교실

연구배경: 특발성폐섬유증 환자의 전형적인 증상은 운동호흡곤란과 마른기침으로, 객담이 적은 원인에 대해서 아직까지 잘 알려져 있지 않다. Interferon- $\gamma$ inducible protein-10 (IP-10)은 여러 호흡기질환과 관련되는데 폐 내로 염증을 유입시 키는데 중요한 역할을 한다. 본 연구는 특발성폐섬유증 환자에서 객담이 적은 기전으로 IP-10이 연관성이 있는지에 대해 연구하였다.

방 법: 특발성폐섬유증 환자를 대상으로 기관지폐포세척액에서 IP-10의 농도를 ELISA로 측정하였다. IP-10이 기도 점액소 발현에 미치는 영향을 간접적으로 알아보기 위해 NCI-H292 세포(점막표피모양 암종 세포주)에서 IP-10을 전처치한 이후 tumor necrosis factor- $\alpha$ (TNF- $\alpha$ )로 자극하여 발현정도를 측정하였다. 이때 점액소 발현과 관련되는 기전으로 epidermal growth factor receptor-mitogen activated protein kinase (EGFR-MAPK)의 신호전달 경로를 알아 보았다.

결 과: IP-10의 기관지폐포세척액내 농도는 특발성폐섬유증 환자가 건강 대조군에 비해 유의하게 높았다. IP-10의 전처치 는 NCI-H292 세포에서 TNF- $\alpha$ 유도 MUC5AC 점액소 발현을 감소시켰는데 이 때 EGFR-MAPK 신호전달 경로의 차단과 관련되었다.

결 론: 특발성폐섬유증 환자의 적은 객담은 IP- 10 의 발현증가와 일부 관련 가능성이 있으며, 이때 IP-10의 작용은 MUC5AC 점액소 유전자 발현에 필요한 EGFR-MAPK 신호전달 경로의 차단과 관련될 것으로 생각한다. (Tuberc Respir Dis 2008;64:347-355)

Key Words: Idiopathic pulmonary fibrosis, MUC5AC, IP-10, Epidermal growth factor receptor, Mitogen-activated protein kinase

\section{Introduction}

Idiopathic pulmonary fibrosis (IPF) is a progressive and irreversible fibrosing lung disease with an estimated incidence of 7 to 11 cases per 100,000 and an estimated prevalence of 27 to 29 per $100,000^{1}$. The hallmark

Address for correspondence: Jeong Sup Song, M.D., Ph.D. Department of Internal Medicine, St. Mary's Hospital, The Catholic University of Korea, 62, Youido-dong, Youngdungpo-gu, Seoul 150-713, Korea

Phone: 82-2-3779-1146, Fax: 82-2-780-3132

E-mail: jssong@catholic.ac.kr

Received: Mar. 24, 2008

Accepted: Apr. 29, 2008 symptoms include dry cough and exertional dyspnea ${ }^{2}$. Clinically, significant cough occurs in more than $80 \%$ of IPF patients. Increased sensitivity to substance $\mathrm{P}$ and capsaicin, along with increased sputum levels of nerve growth factor and brain-derived neurotrophic factor suggest a functional up-regulation of sensory neurons of the lung in IPF patients ${ }^{3}$. However, the pathogenesis of little sputum production, a characteristic symptom of IPF patients, has not yet been elucidated.

Airway mucins are derived from either epithelial goblet cells or epithelial cells of the submucosal gland. At least twenty mucin genes have been reported, four of 
these genes are known to encode gel-forming mucins (MUC2, MUC5AC, MUC5B, MUC6). MUC2 and MUC5AC expression are altered in inflamed airways and, therefore, may contribute to the pathogenesis of several respiratory diseases $^{4-7}$.

Mucin production in respiratory epithelial cells is regulated primarily by the epidermal growth factor (EGF) system ${ }^{8}$. The stimulation of epidermal growth factor receptor (EGFR) by its ligands, EGF and transforming growth factor- $\alpha$ (TGF- $\alpha$ ), causes MUC5AC mucin expression in airway epithelial cells ${ }^{8,9}$, and proinflammatory cytokines such as IL- $1 \beta$, IL-9, and TNF- $\alpha$ can also regulate the expression of specific mucin genes (MUC2, MUC5AC, and MUC8) in airway epithelial cells through a mechanism involving the ERK/MAPK pathway $^{10-12}$, a downstream of EGFR activation ${ }^{9,13,14}$.

Interferon- $\gamma$ inducible protein-10 (IP-10), is a secreted polypeptide of $10 \mathrm{kDa}$ that was first identified as an early response gene induced after interferon- $\gamma$ treatment in a variety of cells; it was therefore named interferon-inducible peptide ${ }^{15}$. IP-10 is a member of the CXC group of chemokines that functions through binding to the receptor CXCR3 on leukocytes such as Th1 lymphocytes, natural killer cells, and macrophages. IP-10 is crucial in leukocyte trafficking into the lung in certain inflammatory diseases or under similar conditions such as asthma, sarcoidosis, T-cell alveolitis, chronic obstructive pulmonary disease, pulmonary fibrosis $^{16-22}$. Previous reports showed IP-10 play an important role in inflammatory cell recruitment into the lung in patients with idiopathic interstitial pneumonia $^{21,22}$.

In this study, we investigated the potential role of IP-10 in regulating mucin expression in the NCI-H292 cell line to begin to elucidate the mechanism of little sputum production in IPF patients.

\section{Materials and Methods}

\section{Measurement of the IP-10 concentration in bron- choalveolar lavage fluid (BALF)}

We enrolled 31 patients with IPF and 9 control sub- jects with normal radiological and functional data for a total of 40 subjects. The characteristics of the patients and control subjects are shown in Table 1. A histological diagnosis was obtained in 17 of the 31 patients with IPF, whereas 14 patients received a diagnosis of IPF without lung biopsy but were in accordance with the diagnostic criteria of the American Thoracic Society (ATS)/European Respiratory Society $(\mathrm{ERS})^{23}$. Patients receiving immunosuppressive drugs and those with neoplastic or systemic infectious diseases at diagnosis were excluded. This study conformed to the Declaration of Helsinki and was approved by the Human Ethics Review Committee of the Catholic University of Korea.

All patients underwent a pulmonary function test and arterial blood gas analysis. The values of forced expiratory volume in $1 \mathrm{~s}\left(\mathrm{FEV}_{1}\right)$, vital capacity $(\mathrm{VC})$, total lung capacity (TLC), and diffusing capacity (DLCO) were expressed as percentages of the predicted values.

With informed consent, bronchoalveolar lavage (BAL) was performed using a flexible fiberoptic bronchoscope

Table 1. Characteristics of the normal control subjects and IPF patients enrolled in the study

\begin{tabular}{lcc}
\hline \multicolumn{1}{c}{ Characteristic } & $\begin{array}{c}\text { Control subjects } \\
(\mathrm{n}=9)\end{array}$ & $\begin{array}{c}\text { IPF patients } \\
(\mathrm{n}=31)\end{array}$ \\
\hline Age, years & $40.0 \pm 6.2$ & $60.9 \pm 1.6$ \\
Sex ratio, M : F & $8: 1$ & $21: 10$ \\
FEV1, \% predicted & $96.2 \pm 2.1$ & $73.8 \pm 3.7^{\star}$ \\
VC, \% predicted & $96.7 \pm 2.3$ & $69.4 \pm 3.6^{*}$ \\
TLC, \% predicted & $102.8 \pm 2.4$ & $69.0 \pm 2.8^{\star}$ \\
DLco, \% predicted & $96.7 \pm 2.9$ & $46.5 \pm 3.6^{\star}$ \\
PO2, mm Hg & $84.8 \pm 1.1$ & $67.0 \pm 2.3^{\star}$ \\
PCO2, mm Hg & $37.1 \pm 0.4$ & $34.7 \pm 0.8$ \\
BALF cell composition: & & \\
Total cells $\times 10^{6}$ & $14.0 \pm 0.8$ & $19.2 \pm 4.0$ \\
Macrophages, \% & $86.9 \pm 3.2$ & $73.3 \pm 6.6$ \\
Lymphocytes, \% & $10.1 \pm 3.2$ & $7.3 \pm 2.3$ \\
Neutrophils, \% & $2.3 \pm 0.9$ & $14.4 \pm 4.4^{*}$ \\
Eosinophils, \% & $0.5 \pm 0.1$ & $5.1 \pm 1.3^{*}$ \\
IP-10 (pg/ml) & $7.4 \pm 3.6$ & $32.2 \pm 4.6^{\dagger}$ \\
\hline
\end{tabular}

Data are presented as means \pm SEM, ${ }^{*} p<0.05$ versus control, ${ }^{+} p<0.01$ versus control. FEV1: forced expiratory volume in 1 s; VC: vital capacity; TLC: total lung capacity; DLco: diffusing capacity; BALF: bronchoalveolar lavage fluid; IP-10: interferon$\gamma$ inducible protein-10. 
wedged into one of the segmental or subsegmental bronchi of the right middle lobe. Then, $30 \mathrm{ml}$ of sterilized saline at body temperature were instilled and retrieved by gentle suction five times through the bronchoscope. The cells were suspended in phosphate-buffered saline (PBS) and counted using a hemocytometer. The supernatants were stored at $-80^{\circ} \mathrm{C}$ until use. The level of IP-10 in BALF samples that were concentrated tenfold was measured with a commercial immunoassay (R\&D Systems, Minneapolis, MN) following the manufacturer's instructions.

\section{Cell culture}

NCI-H292 cells, a human pulmonary mucoepidermoid carcinoma cell line, were grown in RPMI 1640 medium containing 10\% fetal bovine serum, penicillin (100 U/ml), streptomycin $(100 \mu \mathrm{g} / \mathrm{ml})$, and HEPES (25 $\mathrm{mM})$, at $37^{\circ} \mathrm{C}$ and $5 \% \mathrm{CO}_{2}$ in a humidified, water-jacketed incubator. Tumor necrosis factor- $\alpha$ (recombinant human TNF- $\alpha$, $50 \mathrm{ng} / \mathrm{ml}$; R\&D Systems) was used as the stimulus because it was shown to have a potent effect on mucin synthesis in NCI-H292 cells ${ }^{24}$. For the inhibition studies, NCI-H292 cells were pretreated with IP-10 (50 ng/ml; R\&D Systems), a selective EGFR tyrosine kinase inhibitor (AG1478, $50 \mu \mathrm{M}$; Calbiochem, Darmstadt, Germany), or a selective MEK inhibitor (PD98059, $40 \mu \mathrm{M}$; Sigma, St. Louis, MO) $30 \mathrm{~min}$ before incubation with TNF- $\alpha^{7,24,25}$.

\section{Immunoassay of MUC5AC protein}

MUC5AC protein expression was measured by indirect ELISA method. NCI-H292 cell lysates were prepared with lysis buffer, and $50 \mu \mathrm{l}$ of each sample were incubated with bicarbonate-carbonate buffer $(50 \mu 1)$ at $44^{\circ} \mathrm{C}$ in a 96-well plate until dry. The plates were washed three times with PBS and blocked with $2 \%$ bovine serum albumin for 1 hour at room temperature. The plates were again washed three times with PBS, $50 \mu \mathrm{l}$ of mouse anti-human MUC5AC (Neomarker, Fremont, CA) diluted $1: 100$ with blocking solution were added to each well, and the plates were incubated for 1 hour. Then the plates were washed three times with PBS, 100 $\mu 1$ of HRP-conjugated goat anti-mouse IgG (1:2500) was added to each well, and the plates were incubated for 1 hour. After the plates were washed three times with PBS, the color reaction was developed with peroxidase substrate solution containing 3,3',5,5'-tetramethylbenzidine (Kirkegaard \& Perry Laboratories, Gaithersburg, MD) and was stopped with $2 \mathrm{~N} \mathrm{H}_{2} \mathrm{SO}_{4}$. The absorbance was measured at $405 \mathrm{~nm}$. Concentrations were expressed as relative percentages of the control value $(100 \%)$.

\section{Reverse transcriptase-polymerase chain reaction (RT-PCR)}

Total RNA was isolated from NCI-H292 cells using TRIzol $^{\circledR}$ reagent (Invitrogen, Carlsbad, CA), and cDNA was synthesized from $4 \mu \mathrm{g}$ of total RNA using random hexamers as primers and reverse transcriptase. The cDNA was aliquoted into tubes that contained specific primer pairs for the MUC5AC and $\beta$-actin genes. The following primer pairs were used for PCR: MUC5AC (accession No. AF015521), 5'-GTG GAA CCA CGA TGA CAG CCT GC-3' (forward) and 5'-AGA AGC AGC CGG CCA CAC AGT GG-3' (reverse); and $\beta$-actin (accession NO. NM001101), 5'-CAA GAG ATG GCC ACG GCT GCT TCC-3' (forward) and 5'-TCC TTC TGC ATC CTG TCG GCA ATG-3' (reverse). PCR was performed in a thermocycler with an initial denaturation step at $94^{\circ} \mathrm{C}$ for $5 \mathrm{~min}$, followed by 35 cycles of $1 \mathrm{~min}$ at $94^{\circ} \mathrm{C}, 1 \mathrm{~min} 30 \mathrm{~s}$ at $52^{\circ} \mathrm{C}$, and $1 \mathrm{~min}$ at $72^{\circ} \mathrm{C}$, with a final extension for 10 $\min$ at $72^{\circ} \mathrm{C}$. The amplified PCR products were electrophoresed in a $1 \%$ agarose gel and visualized by ethidium bromide staining.

\section{Western blot for EGFR and ERK1/2}

NCI-H292 cells grown in six-well culture plates were serum-starved for 24 hour and then stimulated with TNF- $\alpha(50 \mathrm{ng} / \mathrm{ml})$. For the inhibition studies, IP-10 (50 $\mathrm{ng} / \mathrm{ml}$ ), an EGFR tyrosine kinase inhibitor (AG1478; 50 $\mu \mathrm{M}$ ), or a MEK inhibitor (PD98059; $40 \mu \mathrm{M}$ ) was added to the medium prior to the stimulation with TNF- $\alpha$ for $15 \mathrm{~min}$. The cells were then lysed on ice in protein lysis buffer containing 20 mM Tris- $\mathrm{HCl}$ (pH 7.4), $137 \mathrm{mM}$ 
$\mathrm{NaCl}, 1 \%$ Nonidet P-40, 0.25\% sodium deoxycholate, $0.1 \% \mathrm{SDS}, 1 \mathrm{mM}$ EDTA, $10 \mu \mathrm{g} / \mathrm{ml}$ aprotinin, $1 \mathrm{mM}$ phenylmethylsulfonyl fluoride (PMSF), $0.1 \mathrm{mM}$ sodium vanadate, and $10 \mathrm{mM}$ sodium fluoride. The cellular proteins $(50 \mu \mathrm{g})$ were mixed with sample buffer, denatured with heating at $95^{\circ} \mathrm{C}$ for $10 \mathrm{~min}$, and separated by SDS-PAGE in a 10\% polyacrylamide gel. After electrophoresis, the gel was equilibrated in transfer buffer (15.6 mM Tris-base, $120 \mathrm{mM}$ glycine, 20\% methanol [pH $8.3])$, and the proteins were electrophoretically transferred to polyvinylidene difluoride (PVDF) membranes (Amersham Pharmacia Biotech, Piscataway, NJ). The membranes were blocked with 5\% skim milk in $10 \mathrm{mM}$ Tris-HCl, $150 \mathrm{mM} \mathrm{NaCl}$, and 0.1\% Tween 20 at $\mathrm{pH} 7.5$ (TBST) for 1 hour at room temperature. After blocking, the membranes were incubated overnight with primary antibody (EGFR, 1 : 500; ERK1/2, 1 : 500, Santa Cruz, Delaware, CA) in blocking solution, washed three times with TBST, and incubated with HRP-conjugated anti-rabbit IgG (1 : 2000) for 1 hour. After two additional washes, the signal was developed with $\mathrm{ECL}^{\mathrm{TM}}$ reagent (Amersham Pharmacia Biotech) and detected on X-ray film.

\section{Statistical analysis}

All data are expressed as means \pm SEM using SPSS 10.0 for Windows. Statistical comparisons were made using Student's t-test. A p-value of $<0.05$ denoted a statistically significant difference.

\section{Results}

\section{IP-10 concentration in BALF}

Table 1 shows the characteristics of the IPF patients and normal control subjects. The results of the pulmonary function test, including FEV1, VC, TLC, DLCO, and $\mathrm{PO} 2$, were significantly lower in IPF patients than in control subjects $(p<0.05)$. The BALF of patients with IPF had a higher number of neutrophils and eosinophils than that of the control subjects $(\mathrm{p}<0.05)$. The IP-10 concentration was elevated in the BALF of IPF patients (32.2 $\pm 4.6 \mathrm{pg} / \mathrm{ml})$ compared to that of the control sub-

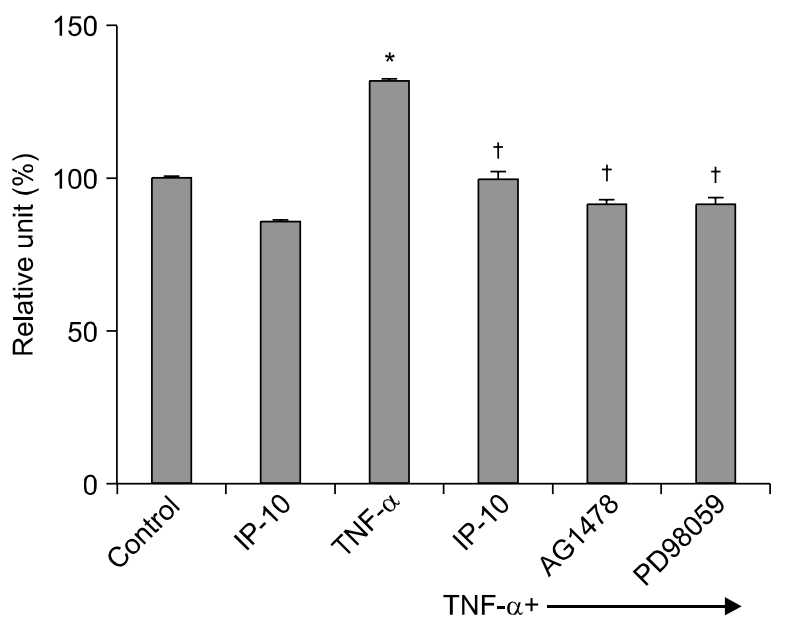

Figure 1. Effect of IP-10 on MUC5AC mucin protein expression determined by ELISA assay in NCl-H292 cells. $\mathrm{NCl}-\mathrm{H} 292$ cells were pretreated with IP-10 (50 ng/ml) or EGFR tyrosine kinase inhibitor (AG1478, $50 \mu \mathrm{M})$ or MEK inhibitor (PD98059, $40 \mu \mathrm{M})$ for $30 \mathrm{~min}$, followed by incubation with TNF- $\alpha(50 \mathrm{ng} / \mathrm{ml})$ for 24 hour. MUC5AC expression significantly increased after TNF- $\alpha$ stimulation. IP-10 or the signal transduction inhibitors AG1478 or PD98059 significantly suppressed the expression of MUC5AC protein $\left({ }^{*} p<0.01\right.$, compared to control, ${ }^{+} p$ $<0.01$, compared to TNF- $\alpha$ stimulation alone).

jects $(7.4 \pm 3.6 \mathrm{pg} / \mathrm{ml}, \mathrm{p}<0.01)$.

\section{MUC5AC protein expression}

An ELISA was used to measure MUC5AC protein in NCI-H292 cells. MUC5AC expression significantly increased after TNF- $\alpha$ stimulation $(\mathrm{p}<0.01)$. Pretreatment with IP-10, or the signal transduction inhibitors of EGFR tyrosine kinase (AG1478) or of MEK (PD98059) significantly suppressed the expression of MUC5AC protein (Figure 1).

\section{MUC5AC mRNA expression}

The RT-PCR analysis of RNA from NCI-H292 cells revealed that the expression of MUC5AC mRNA significantly increased after TNF- $\alpha$ stimulation. Pretreatment with IP-10 or the signal transduction inhibitors AG1478 or PD98059 significantly suppressed the expression of MUC5AC mRNA. The $\beta$-actin gene was used as a control (Figure 2). 

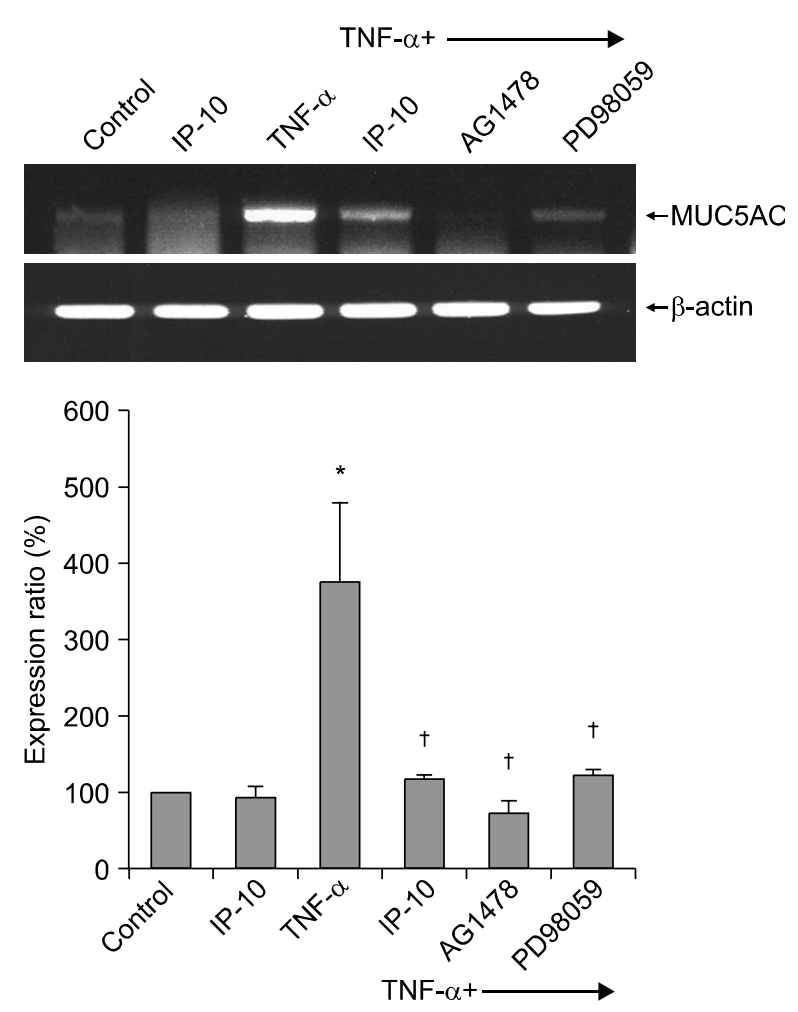

Figure 2. RT-PCR analysis of MUC5AC mRNA expression in NCl-H292 cells. NCl-H292 cells were pretreated with IP-10 (50 ng/ml) or EGFR tyrosine kinase inhibitor (AG1478, $50 \mu \mathrm{M}$ ) or MEK inhibitor (PD98059, $40 \mu \mathrm{M}$ ) for $30 \mathrm{~min}$, followed by incubation with TNF- $\alpha(50 \mathrm{ng} / \mathrm{ml})$ for 24 hour. The expression of MUC5AC mRNA significantly increased after TNF- $\alpha$ stimulation. IP-10 or the signal transduction inhibitors AG1478 or PD98059 significantly suppressed the expression of MUC5AC mRNA $\left({ }^{*} p<0.01\right.$, compared to control, ${ }^{\dagger} p<0.01$, compared to TNF- $\alpha$ stimulation alone).

\section{EGFR and ERK1/2 phosphorylation}

A Western blot analysis was performed to examine the levels of EGFR, phosphorylated EGFR, ERK, and phosphorylated ERK. The amount of phosphorylated EGFR was significantly increased after TNF- $\alpha$ stimulation and was significantly decreased after pretreatment with IP-10 or the EGFR tyrosine kinase inhibitor AG1478 (Figure 3). Similarly, the amount of phosphorylated ERK1/2 was significantly increased after TNF- $\alpha$ stimulation and was significantly decreased after pretreatment with IP-10 or the MEK inhibitor PD98059 (Figure 4).

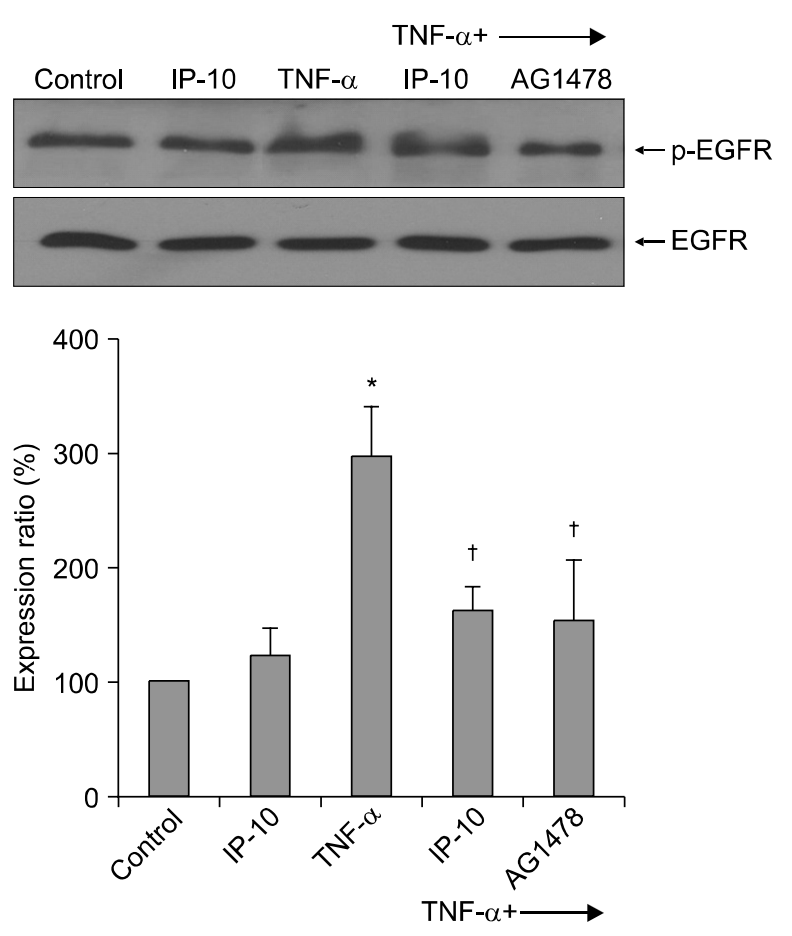

Figure 3. Effect of IP-10 on the phosphorylation of EGFR in NCl-H292 cells. NCl-H292 cells were pretreated with IP-10 $(50 \mathrm{ng} / \mathrm{ml})$ or EGFR tyrosine kinase inhibitor (AG1478, $50 \mu \mathrm{M}$ ) for $30 \mathrm{~min}$, followed by incubation with TNF- $\alpha(50 \mathrm{ng} / \mathrm{ml})$ for $15 \mathrm{~min}$. EGFR phosphorylation significantly increased after TNF- $\alpha$ stimulation. IP-10 or the signal transduction inhibitor AG1478 significantly suppressed EGFR phosphorylation $\left({ }^{*} \mathrm{p}<0.05\right.$, compared to control, ${ }^{\dagger} p<0.05$, compared to TNF- $\alpha$ stimulation alone).

\section{Discussion}

In the present study, IPF patients showed significantly increased IP-10 concentration in BALF compared to the control subjects, and in NCI-H292 cells, IP-10 reduces MUC5AC mRNA expression through the inhibition of the EGFR-MAPK pathway which suggests little sputum productions in IPF patients could be attributable to IP-10 overproduction. IPF is a progressive and irreversible fibrosing lung disease characterized by remodeling of the lung parenchyma and collagen deposition. Currently, the pathogenesis of the disease remains unknown. Although this study did not evaluate mucin in BALF or in tissue biopsy samples from IPF patients, we measured the increased MUC5AC expression using the hu- 


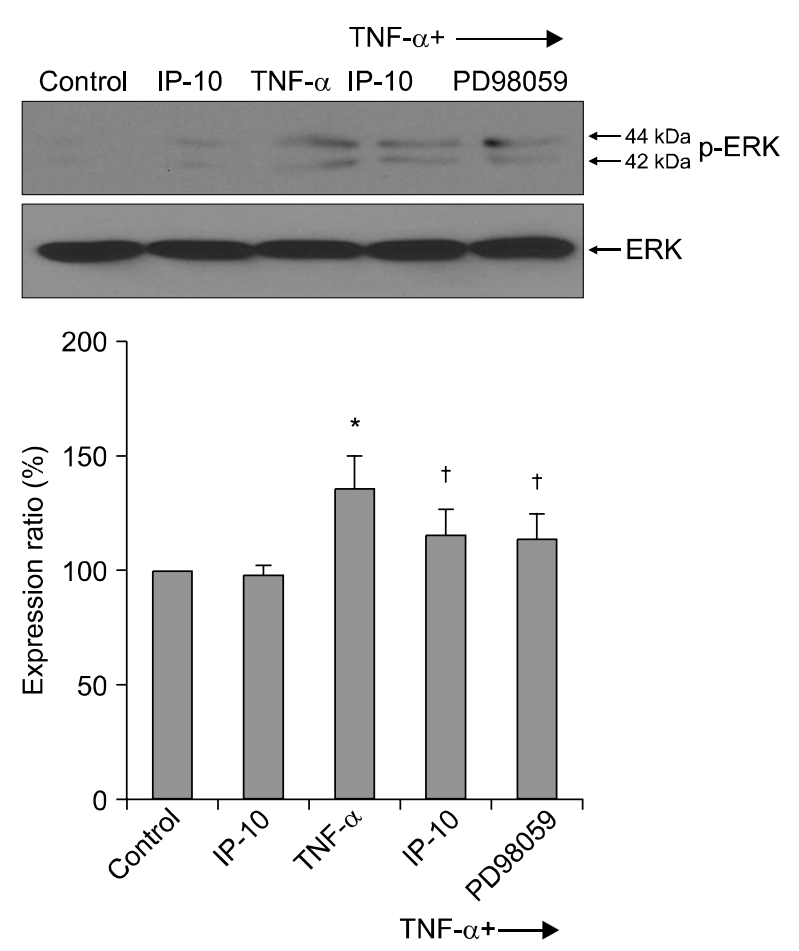

Figure 4. Effect of $\mathbb{I P}-10$ on the phosphorylation of ERK1/2 in NCl-H292 cells. NCl-H292 cells were pretreated with IP-10 (50 ng/ml) or MEK inhibitor (PD98059, $40 \mu \mathrm{M})$ for $30 \mathrm{~min}$, followed by incubation with TNF- $\alpha$ $(50 \mathrm{ng} / \mathrm{ml})$ for $15 \mathrm{~min}$. ERK $1 / 2$ phosphorylation significantly increased after TNF-? stimulation. IP-10 or the signal transduction inhibitor PD98059 significantly suppressed ERK $1 / 2$ phosphorylation $\left({ }^{*} \mathrm{p}<0.05\right.$, compared to control, ${ }^{+} p<0.05$, compared to TNF- $\alpha$ stimulation alone).

man pulmonary mucoepidermoid carcinoma cell line NCI-H292, after TNF- $\alpha$ stimulation. This elevated transcriptional activity as well as the increased signal transduction responses of p-EGFR and p-ERK after TNF- $\alpha$ stimulation were inhibited by pretreatment with IP-10 or the EGFR tyrosine kinase inhibitor AG1478 or the MEK inhibitor PD98059.

Mucins are glycoproteins of high molecular weight and are composed of 10 to $20 \%$ protein and 80 to $90 \%$ complex carbohydrates. Mucin synthesis in airways is regulated by the EGFR system, and the activation of EGFR cascade leads to the synthesis of mucin at both the mRNA and protein levels ${ }^{8,9}$. In this study, we used TNF- $\alpha$ to stimulate mucin production because previous reports had established TNF- $\alpha$ as a potent effector of major mucin synthesis ${ }^{24,26}$.

EGFR is a member of the receptor tyrosine kinase superfamily and is involved in the regulation of cellular proliferation and differentiation, primarily in epithelial cell types. MAPKs are a family of proline-targeted, serine?threonine kinases that transduce environmental stimuli to the nucleus. Mammals express at least four groups of MAPKs: extracellular signal-related kinases (ERK)-1 and -2, p38 kinases, ERK-5, and c-Jun amino-terminal kinases (JNK 1, 2, and 3$)^{13}$.

The activation of EGFR is followed by the stimulation of several signaling pathways, including the MAPKs p38, JNK, ERK1/2, and big MAPK (BMK, ERK5), which subsequently results in the activation of various transcription factors (e.g., activator protein-1 and nuclear factor-kB) and gene transcription. Among the MAPKs, the three interconnected, relatively well-described pathways are the JNK, ERK, and p38 pathways. Each cascade is composed of at least three enzymes activated in series. The ERK1/2 (p44 and p42) pathways are the best characterized among the group. In the present study, IP-10 and PD98059 inhibited the production of phosphorylated ERK1/2. Takeyama et al. ${ }^{8}$ suggested that EGFR cascade inhibitors could have potential roles for hypersecretory airway diseases. In this study, for the evaluation of mucin synthesis inhibition we used known EGFR cascade inhibitors, AG1478 and PD98059, and compared them with IP-10 which might have important role in the pathogenesis of IPF.

Baughman et al. ${ }^{27}$ demonstrated that the expression of TGF- $\alpha$ and EGFR was elevated in the lung tissue of patients with IPF. Thus, one may presume that mucin production in IPF patients would increase as a result of the overexpression of EGFR and its ligand. However, one symptom of IPF is a dry cough rather than a productive cough. Based on the results of the present study, the overexpression of TGF- $\alpha$ and EGFR is not likely to induce increased mucin production. These findings suggest the existence of a blocking pathway between EGFR and mucin production.

Interferon- $\gamma$ inducible protein-10 (IP-10), a potent ELR-CXC chemokine, is induced in monocytes/macro- 
phages by interferon- $\gamma$ and causes chemotaxis of lymphocytes, preferentially activated Th1 cells ${ }^{15,28,29}$. In certain pulmonary diseases such as sarcoidosis, tuberculosis, HIV-associated T cell alveolitis, and chronic obstructive pulmonary disease, IP-10 is an important mediator in the recruitment of activated lymphocytes into the lungs ${ }^{17-20}$.

Mucous hypersecretion is one of the common features in asthmatic airways. Some studies demonstrated that IP-10 was up-regulated in the airways of asthmatics and a mouse model of allergic pulmonary inflammation $^{16,30}$. These previous findings in asthmatic airways that IP-10 overproduction could be associated with increased mucous hypersecretion were inconsistent with our results. This inconsistency could be explained that the degree of relative expression of Th1 and Th2 balance in the cytokine network of asthmatic airways might be more important than the absolute concentration of a cytokine. The role of IP-10 in asthmatic patients remains to be known.

In this study, although the IPF patients had higher ages than the control subjects, IP-10 in BALF of IPF patients showed increased concentration compared to the control subjects, which was similar results of previous studies $^{21,22}$. However, in a study of the pathogenesis of angiogenic (IL-8) and angiostatic (IP-10) CXC chemokines in IPF, Keane et al. ${ }^{31}$ showed a decreased IP-10 level and increased IL-8 level in lung biopsy specimens from IPF patients. This discrepancy of IP-10 level between BALF and lung tissue specimens would need further studies, but could be attributed to potential compartmentalization between BALF and lung tissue of IPF patients.

Shiraha et al. $^{32}$ indicated an association between IP-10 and the EGFR signaling pathway, demonstrating an inhibition by IP-10 of EGF-induced cell motility but not proliferation. They suggested that this inhibition occurred at a point beyond the EGF receptor in the cascade because upstream EGFR signaling pathways were not affected by IP-10. As few studies have been published on the role of IP-10 in the EGFR signaling pathway during the pathogenesis of IPF, our results, which clearly show that the EGFR-MAPK signal transduction pathway is inhibited by IP-10 pretreatment, are noteworthy.

In conclusion, we suggested a role of IP-10 in the pathogenesis of dry cough exhibited by IPF patients. This might be the first report suggesting that little sputum production in IPF patients could be attributable to the decreased expression of mucin mediated by IP-10 through the inhibition of EGFR- and ERK-dependent phosphorylation in mucin-secreting respiratory epithelial cells.

\section{Summary}

Background: IPF is characterized by chronic, fibrosing inflammatory lung disease of unknown etiology. Typical symptoms of IPF are exertional dyspnea with nonproductive cough. Why patients with typical IPF have dry cough rather than productive cough, is unknown. IP-10 plays an important regulatory role in leukocyte trafficking into the lung. The present study investigated the effect of IP-10 in the pathogenesis of dry cough rather than productive cough in IPF patients.

Methods: IP-10 concentration was measured by ELISA from BALF of IPF patients. To evaluate the role of IP-10 in mucin expression, the expression of the MUC5AC mucin gene was measured in NCI-H292 cells, a human pulmonary mucoepidermoid carcinoma cell line, after stimulation by TNF- $\alpha$ with or without IP-10 pretreatment. EGFR-MAPK expression was also examined as a possible mechanism.

Results: IP-10 levels were significantly higher in the BALF of IPF patients compared to healthy controls. IP-10 pretreatment reduced TNF- $\alpha$ induced MUC5AC mucin expression by inhibiting the EGFR-MAPK signal transduction pathway in NCI-H292 cells.

Conclusion: These findings suggest that little mucus production in IPF patients might be attributable to IP-10 overproduction, which inhibits the EGFR-MAPK signal transduction pathway required for MUC5AC mucin gene expression. 


\section{References}

1. Coultas DB, Zumwalt RE, Black WC, Sobonya RE. The epidemiology of interstitial lung diseases. Am J Respir Crit Care Med 1994;150:967-72.

2. Johnston ID, Prescott RJ, Chalmers JC, Rudd RM. British Thoracic Society study of cryptogenic fibrosing alveolitis: current presentation and initial management. Fibrosing Alveolitis Subcommittee of the Research Committee of the British Thoracic Society. Thorax 1997;52:38-44.

3. Brown KK. Chronic cough due to chronic interstitial pulmonary diseases: ACCP evidence-based clinical practice guidelines. Chest 2006;129:180S-5S.

4. Voynow JA, Selby DM, Rose MC. Mucin gene expression (MUC1, MUC2, and MUC5/5AC) in nasal epithelial cells of cystic fibrosis, allergic rhinitis, and normal individuals. Lung 1998;176:345-54.

5. Vinall LE, Fowler JC, Jones AL, Kirkbride HJ, de Bolos C, Laine A, et al. Polymorphism of human mucin genes in chest disease: possible significance of MUC2. Am J Respir Cell Mol Biol 2000;23:678-86.

6. Chorley BN, Crews AL, Li Y, Adler KB, Minnicozzi M, Martin LD. Differential Muc2 and Muc5ac secretion by stimulated guinea pig tracheal epithelial cells in vitro. Respir Res 2006;7:35.

7. Song JS, Kang CM, Yoo MB, Kim SJ, Yoon HK, Kim YK, et al. Nitric oxide induces MUC5AC mucin in respiratory epithelial cells through PKC and ERK dependent pathways. Respir Res 2007;8:28.

8. Takeyama K, Dabbagh K, Lee HM, Agusti C, Lausier JA, Ueki IF, et al. Epidermal growth factor system regulates mucin production in airways. Proc Natl Acad Sci U S A 1999;96:3081-6.

9. Bogdan S, Klambt C. Epidermal growth factor receptor signaling. Curr Biol 2001;11:R292-5.

10. Louahed J, Toda M, Jen J, Hamid Q, Renauld JC, Levitt $\mathrm{RC}$, et al. Interleukin-9 upregulates mucus expression in the airways. Am J Respir Cell Mol Biol 2000;22:64956.

11. Song KS, Lee WJ, Chung KC, Koo JS, Yang EJ, Choi JY, et al. Interleukin-1 beta and tumor necrosis factor-alpha induce MUC5AC overexpression through a mechanism involving ERK/p38 mitogen-activated protein kinases-MSK1-CREB activation in human airway epithelial cells. J Biol Chem 2003;278:23243-50.

12. Song KS, Seong JK, Chung KC, Lee WJ, Kim CH, Cho $\mathrm{KN}$, et al. Induction of MUC8 gene expression by interleukin-1 beta is mediated by a sequential ERK MAPK/
RSK1/CREB cascade pathway in human airway epithelial cells. J Biol Chem 2003;278:34890-6.

13. Chang L, Karin M. Mammalian MAP kinase signalling cascades. Nature 2001;410:37-40.

14. Liebmann C. Regulation of MAP kinase activity by peptide receptor signalling pathway: paradigms of multiplicity. Cell Signal 2001;13:777-85.

15. Luster $\mathrm{AD}$, Ravetch JV. Biochemical characterization of a gamma interferon-inducible cytokine (IP-10). J Exp Med 1987;166:1084-97.

16. Miotto D, Christodoulopoulos P, Olivenstein R, Taha R, Cameron L, Tsicopoulos A, et al. Expression of IFNgamma-inducible protein; monocyte chemotactic proteins 1, 3, and 4; and eotaxin in TH1- and TH2-mediated lung diseases. J Allergy Clin Immunol 2001;107:66470 .

17. Agostini C, Cassatella M, Zambello R, Trentin L, Gasperini S, Perin A, et al. Involvement of the IP-10 chemokine in sarcoid granulomatous reactions. J Immunol 1998;161:6413-20.

18. Sauty A, Dziejman M, Taha RA, Iarossi AS, Neote K, Garcia-Zepeda EA, et al. The T cell-specific CXC chemokines IP-10, Mig, and I-TAC are expressed by activated human bronchial epithelial cells. J Immunol 1999;162:3549-58.

19. Agostini C, Facco M, Siviero M, Carollo D, Galvan S, Cattelan AM, et al. CXC chemokines IP-10 and mig expression and direct migration of pulmonary $\mathrm{CD} 8+$ / CXCR3 $+\mathrm{T}$ cells in the lungs of patients with HIV infection and T-cell alveolitis. Am J Respir Crit Care Med 2000;162:1466-73.

20. Saetta M, Mariani M, Panina-Bordignon P, Turato G, Buonsanti C, Baraldo S, et al. Increased expression of the chemokine receptor CXCR3 and its ligand CXCL10 in peripheral airways of smokers with chronic obstructive pulmonary disease. Am J Respir Crit Care Med 2002;165:1404-9.

21. Nakayama S, Mukae H, Ishii H, Kakugawa T, Sugiyama $\mathrm{K}$, Sakamoto N, et al. Comparison of BALF concentrations of ENA-78 and IP10 in patients with idiopathic pulmonary fibrosis and nonspecific interstitial pneumonia. Respir Med 2005;99:1145-51.

22. Pignatti P, Brunetti G, Moretto D, Yacoub MR, Fiori M, Balbi B, et al. Role of the chemokine receptors CXCR3 and CCR4 in human pulmonary fibrosis. Am J Respir Crit Care Med 2006;173:310-7.

23. American Thoracic Society; European Respiratory Society. American Thoracic Society/European Respiratory Society International Multidisciplinary Consensus 
Classification of the Idiopathic Interstitial Pneumonias. This joint statement of the American Thoracic Society (ATS), and the European Respiratory Society (ERS) was adopted by the ATS board of directors, June 2001 and by the ERS Executive Committee, June 2001. Am J Respir Crit Care Med 2002;165:277-304.

24. Takeyama K, Dabbagh K, Jeong Shim J, Dao-Pick T, Ueki IF, Nadel JA. Oxidative stress causes mucin synthesis via transactivation of epidermal growth factor receptor: role of neutrophils. J Immunol 2000;164:154652.

25. Song JS, Cho KS, Yoon HK, Moon HS, Park SH. Neutrophil elastase causes MUC5AC mucin synthesis via EGF receptor, ERK and NF-kB pathways in A549 cells. Korean J Intern Med 2005;20:275-83.

26. Levine SJ, Larivee P, Logun C, Angus CW, Ognibene $\mathrm{FP}$, Shelhamer JH. Tumor necrosis factor-alpha induces mucin hypersecretion and MUC-2 gene expression by human airway epithelial cells. Am J Respir Cell Mol Biol 1995;12:196-204.

27. Baughman RP, Lower EE, Miller MA, Bejarano PA, Heffelfinger SC. Overexpression of transforming growth factor-alpha and epidermal growth factor-receptor in idiopathic pulmonary fibrosis. Sarcoidosis Vasc Diffuse
Lung Dis 1999;16:57-61.

28. Taub DD, Lloyd AR, Conlon K, Wang JM, Ortaldo JR, Harada A, et al. Recombinant human interferon-inducible protein 10 is a chemoattractant for human monocytes and $\mathrm{T}$ lymphocytes and promotes $\mathrm{T}$ cell adhesion to endothelial cells. J Exp Med 1993;177:180914.

29. Liu L, Callahan MK, Huang D, Ransohoff RM. Chemokine receptor CXCR3: an unexpected enigma. Curr Top Dev Biol 2005;68:149-81.

30. Medoff BD, Sauty A, Tager AM, Maclean JA, Smith RN, Mathew A, et al. IFN-gamma-inducible protein 10 (CXCL10) contributes to airway hyperreactivity and airway inflammation in a mouse model of asthma. J Immunol 2002;168:5278-86.

31. Keane MP, Arenberg DA, Lynch JP 3rd, Whyte RI, Iannettoni MD, Burdick MD, et al. The CXC chemokines, IL-8 and IP-10, regulate angiogenic activity in idiopathic pulmonary fibrosis. J Immunol 1997;159: 1437-43.

32. Shiraha H, Glading A, Gupta K, Wells A. IP-10 inhibits epidermal growth factor-induced motility by decreasing epidermal growth factor receptor-mediated calpain activity. J Cell Biol 1999;146:243-54. 